\title{
The Impact of Product Attributes, Personality, and Word of Mouth on Purchase Intention Product of Gift of Typical Food of West Sumatera
}

\author{
Rizni Aulia Qadri' ${ }^{1}$, Yasri ${ }^{2}$ \\ ${ }^{1}$ Universitas Negeri Padang, Padang, Indonesia, $₫$ rizniaulia37@gmail.com \\ ${ }^{2}$ Universitas Negeri Padang, Padang, Indonesia, \yasri33@fe.unp.ac.id
}

\begin{abstract}
This study aims to analyze the effect of product attributes, personality and word of mouth on the purchase intention of from West Sumatra's gift typical food product. The population in this study are tourists who have the intention to buy gift typical food from West Sumatra. While the sample in this study was determined by purposive sampling method with the method of Hair calculation, so that for sample of 350 respondents was obtained. Data type used in this research is primary data. This study uses the Structural Equation Modeling (SEM) analysis method. The results of this study indicate that (1) product attributes have a significant and positive impact on purchase intention, (2) personality has a positive and significant effect on purchase intention, and (3) word of mouth has a positive and significant effect on purchase intention
\end{abstract}

Keywords: Product Attributes, Personality, Word of Mouth, Purchase Intention, Hair

\section{Introduction}

The current tourist trend is to come to a tourist area to find or hunt regional specialties and not hesitate to pay dearly to be able to enjoy the region's special food. Many new restaurants and eateries were established with their respective qualifications and characteristics. Tourists state that West Sumatra tourism is quite interesting. This area has a variety of uniqueness, both natural conditions, culture, food and gift (Yasri, 2009). West Sumatra is a province known as the number one most delicious food producer in the world of is rendang. In addition to rendang, some of the most popular gift typical foods are sanjai, kripik balado, karak kaliang, kerupuk jangek, kerupuk jariang, kripik talas, kripik kentang, kripik pisang, rendang daging, rendang telur, rendang runtiah, rendang paru, dendeng, bareh rendang, galamai, dadiah, batiah, kipang kacang, pinyaram, aria pinang, kue sapik, roti rendang, roti durian, mande cake, peyek/rakik, ikan bilih, rinuak, kacang tujin, typical Sumatran Kiniko coffee and others.

SMEs are the foundation of the economy of West Sumatra, because in this area there are no large companies that support the regional economy. Therefore, employment and community income depend on the development of these MSMEs. Besides that, this area has always been known for its relatively tasty and many foods. But in line with the development of globalization, food businesses in West Sumatra face increasingly sharp competition. Food products from neighboring countries such as Malaysia, Thailand and China are increasingly entering this area and this condition threatens the existence of MSMEs in the food sector. Thus efforts to build competitive advantage (Yasri, 2009).

Product attributes (packaging, brand, label, information in the label, expiry date and price) of products from abroad are very complete. Based on the observations of researchers during the field, product brands which are names, terms, symbols, designs, colors are still not neatly arranged. While packaging or packaging is one of the spearheads of selling a product, it has not been able to grow consumer interest in buying. Interest is an ability that drives things to do. Interest is not the same as motives or encouragement. Someone who gets encouragement is not necessarily willing to implement it if he is not interested. But on the contrary if someone has a strong interest to do and coupled with impulses tend, he will do it happily. Schiffman\&Kanuk (2000: 206) purchase intention is a form of real thought from the reflection of the buyer's plan to buy several units in a certain number of brands available in a certain period of time. The interest in buying consumers to buy can arise due to the stimulus (stimulus) 
offered by the company. Each stimulus is designed to produce actions to buy from consumers. According to Jin\& Kang (2011) revealed that purchase intention relating four consumer behaviors including doubtful plans to buy products, when someone ponders to buy products in the future and to buy certain products.Many factors influence purchase intention. According to Paul \& Rana (2012); Jundong, Lanying, \&Jianfeng (2008) factors that influence purchase intention include product attributes, involvement, personality and word of mouth (WOM). Of the many factors that influence researchers focus on product attributes, personality and WOM.

Product attributes (brand, packaging, labeling, complementary services, guarantees and prices). Brands can provide product identity and differentiation towards competing products. Consumers will easily recognize a product through the product brand. While packaging or packaging is the first thing consumers see when shopping. If the packaging has an attractive appearance, consumers will be interested and intend to buy the product. According to Kotler \& Keller (2018) suggest that in the alternative evaluation phase, consumers will see a product as a combination of attributes with capabilities that can provide certain benefits and are able to form buying interest. Based on the results of Kolopita\&Soegoto's research (2015); Sidik\&Saino (2014) can be seen that product attributes influence buying interest.

In addition to product attribute factors, the factors that influence shopping interest are personality. Personality is a pattern of one's habits that is influenced by the closest environment in making choices, then expressed in an action. It can be assumed that consumer taste can change throughout life and have an influence on brand selection in various stages of life. According to Kotler \& Armstrong (2018) personality is a characteristic that is specific to someone and may not be related to other people in the same group. Purchase intent refers to the probability, possibility, and willingness of consumers to buy a product, or maybe the consumer's plan to buy a product (Dodds, Monroe, \& Grewal, 2006). Personality factors such as imaginative, reliable, charming, etc. affect consumer evaluations (Khare, Khare, \& Singh, 2010).

Furthermore, the factors that influence purchase intention are WOM. If someone receives positive information on the first information, it will form a positive attitude, positive information about WOM cannot change. If WOM communication is carried out every day by someone based on experience with a product. The more often a person receives a positive thing about a product, the higher the feeling of wanting to have a product. This is in accordance with the research conducted by Chowtanapanich and Chaipoopirutana (2014) revealing that WOM communication has a positive effect on buying interest. Successful products can be affected by positive word of mouth and reduced word of mouth negative (McGriff, 2012).

Research on purchase intention has been carried out by researchers including Lee, Cheng, \& Shih (2017), and Evanita\&Trinanda (2018) showing that product attributes have a positive and significant influence on purchase intention. Research conducted by Novita \&Lubis (2018) and Ghoni\&Bodroastuti (2012), in the study found positive influences between personality and purchase intention. Rachman and Abadi (2017), Li et al (2017), and Yasri\&Engriani (2018) state that wom has a positive effect on purchase intention.

Based on the background above, the researcher is interested in conducting research with the title: "The Impact of Product Attributes, Personality, and Word of Mouth On Purchase Intention of the Product of Gift of Typical Food of West Sumatra"

\section{Methods}

This research is a study of the Impact of product attributes, personality, and word of mouth on purchase intention of the product of the gift of typical food of West Sumatra, with a total sample of 350 respondents selected based on purposive sampling technique. The sample selection criteria in this study 
are tourists who have the intention to buy gift from West Sumatra. The data analysis technique used is Scructural Equation Modeling (SEM) analysis.

SEM analysis is used to determine the effect of the independent variables of product attributes, personality and word of mouth on the purchase intention of the product of the gift of typical food of West Sumatra.

\section{Result and Discussion}

The purpose of overall measurement model is to analyze the validity and fit models of the three latent variables simultaneously. If the overall measurement of this model can meet the requirements of convergent validity and model fit then the model can be continued to the next stage of the structural model. The results of the overall measurement model as follow:

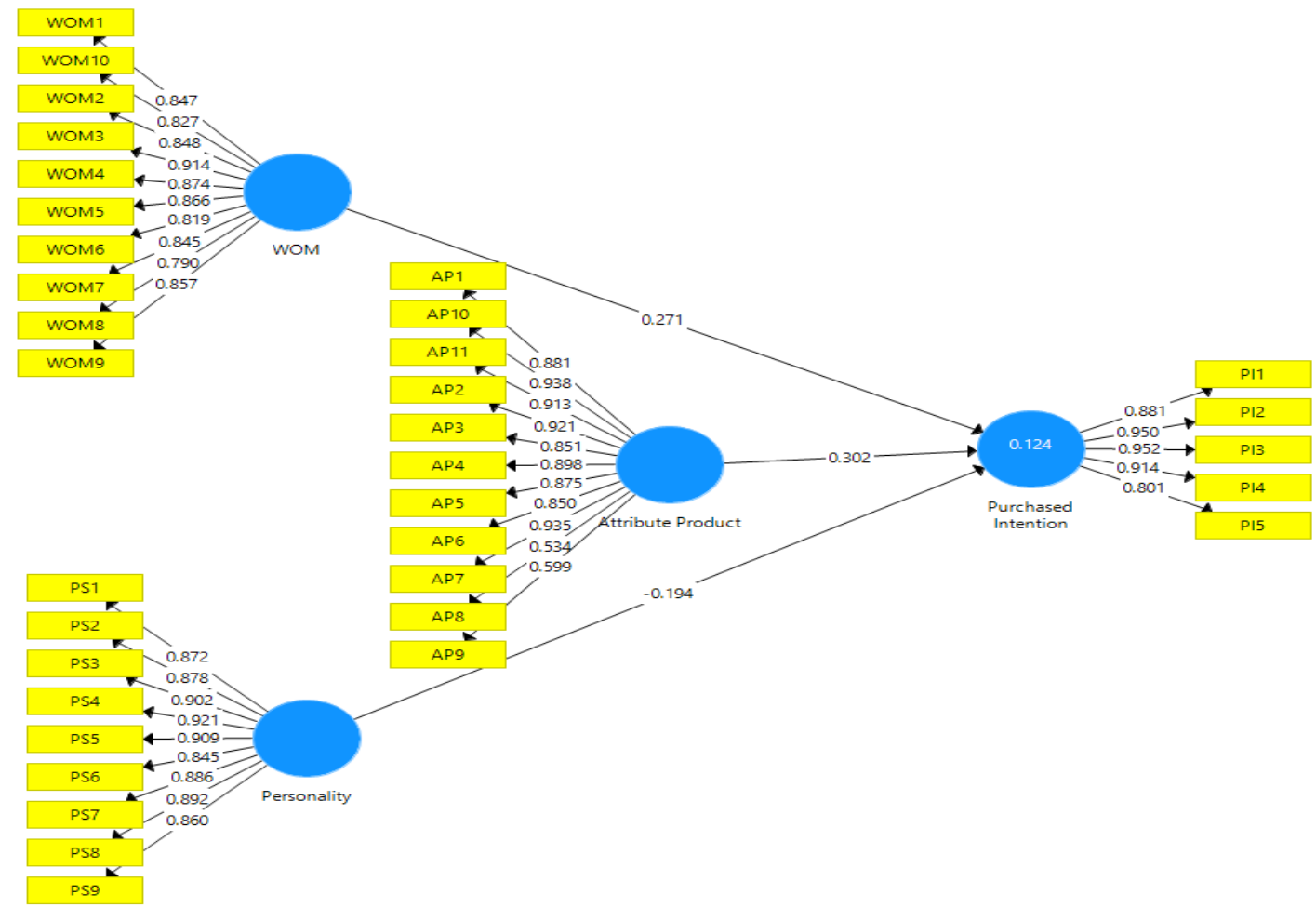

Figure 1 Overall Measurement Model

Analysis of Variant (R2) or Determination Test is to find out the influence of the independent variable on the dependent variable, the value of the coefficient of determination can be shown in the following Table:

Table 1 R Square

\begin{tabular}{crc}
\hline Variable & R Square & R Square Adjusted \\
\hline Purchased Intention & 0,124 & 0,116 \\
\hline
\end{tabular}

In this study, it can be seen that R2 purchase intention is 0.124 , which means that product, personality, and WOM variables explain purchase intention variables at $12.4 \% \%$ and the remaining $87.6 \%$ is explained by other extracts outside of the research.

From processing data with SmartPLS version 3, the results are obtained as in the following table: 
Table 2 Results of Path Coefficients

\begin{tabular}{lccrrr}
\hline & $\begin{array}{c}\text { Original Sample } \\
\text { (O) }\end{array}$ & $\begin{array}{c}\text { Sample } \\
\text { Mean } \\
(\mathbf{M})\end{array}$ & $\begin{array}{c}\text { Standard } \\
\text { Deviation } \\
\text { (STDEV) }\end{array}$ & $\begin{array}{c}\text { T Statistics } \\
(\mid \mathbf{O} / \text { STDEV I) }\end{array}$ & P Values \\
\hline $\begin{array}{l}\text { Attribute Product -> } \\
\text { Purchased Intention }\end{array}$ & 0,302 & 0,302 & 0,050 & 6,036 & 0,000 \\
\hline $\begin{array}{l}\text { Personality -> Purchased } \\
\text { Intention }\end{array}$ & 0,194 & 0,172 & 0,098 & 1,985 & 0,047 \\
\hline WOM -> Purchased Intention & 0,271 & 0,260 & 0,096 & 2,806 & 0,005 \\
\hline
\end{tabular}

Based on the table above shows that the results of hypothesis testing based on beta values and pvalue $0.05(5 \%)$ can be concluded that:

The first hypothesis test results are positive and $p$-value $=0,000$. This shows that attribute products have a positive and significant effect on purchase intention. This means that the better the attribute product is more influential on purchase intention. In other words, in this study attribute product has an influence on purchase intention, so the hypothesis is accepted.

The second hypothesis test results are positive and $p$-value $=0.047$. This shows that personality has a positive and significant effect on purchase intention. This means that the better the personality the more influential the purchase intention. In other words, in this study personality gives influence to purchase intention, so the hypothesis is accepted.

The third hypothesis test results are positive and $\mathrm{p}$-value $=0.005$. This shows that WOM has a positive and significant effect on purchase intention. This means that more often doing WOM is increasingly influential on purchase intention. In other words, in this study WOM has an influence on purchase intention, so the hypothesis is accepted.

First, gift of typical West Sumatra food are foods that are familiar to local, domestic and foreign tourists. West Sumatra's specialty food products have clear product information, a variety of flavors, interesting colors, which are used to distinguish West Sumatra typical food products from other regional products. Based on the results of hypothesis testing it is known that product attributes have a significant and positive effect on the purchase intention of typical West Sumatra food products. That is, the better the attributes of gift products typical of West Sumatra food, the higher the consumer purchase intention of gift of typical West Sumatra food products

Research that is in line with this research is the research conducted by Lee, Cheng, \& Shih (2017); Safriadi and Hardyaniwati (2017) and Setyanto (2017) who suggest that product attributes of a product have a positive influence on the purchase intention of a product such as product information, product quality and the price of the product itself. Evanita\&Trinanda's (2018) study of the effect of product attributes on buying snacks for traditional snacks for adolescents in urban areas in West Sumatra stated that the product attributes had a significant effect on the interest in buying traditional snacks for teenagers in urban West Sumatra. Companies must always maintain and improve the quality of product attributes, both in terms of labeling, packaging, raw materials and the benefits of the product itself because it has a very dominant and significant influence. Based on the opinion above it can be concluded that product information, product quality and prices included in product attributes affect the purchase intention of gift products typical of West Sumatra food.

Second, Based on the results of the analysis show that personality has a significant and positive effect on purchase intention to buy gift from West Sumatra. Where the nature of a person influences him to shop. The better a person's personality, the attitude, actions and reactions to decide an action or interaction that he will do the better too. The results of this study are in line with the results of research 
conducted by and Novita \&Lubis (2018) and Ghoni\&Bodroastuti (2012) personal factors have a positive effect on the purchase intention process. And supported by the research of Thu Ha \&Gizaw (2014) states that personal factors have a positive effect on purchase intention which will lead to an action that is making a purchase decision in the selection of products to be purchased. From the explanation above, it can be concluded that extraversion, agreement, caution, emotional stability, and openness to new things or those related to one's personality can influence the intention to buy gift from West Sumatra.

And last, Based on the results of the analysis, WOM has a significant and positive effect on the purchase intention to shop for gift from West Sumatra. This means that recommendations and communications that are carried out directly or through the internet, namely websites, twitter, facebook, Instagram have a positive and significant influence on purchase intention. This is unwittingly, WOM communication is carried out every day. Activities are often considered free advertising, because someone tells the experience of a product. The more often a person receives a positive thing about a product, the higher the feeling of wanting to have a product. The importance of WOM is also recognized in business as a way to intensify promotion, in general the spread of word of mouth and social media is more effective, the impact can be good or bad. WOM is forming products that are suitable for sale and consumption for tourists as gift of the most desirable foods as gift products typical of West Sumatra. With the existence of WOM this is very helpful for consumers in purchasing. Based on the opinions above, it can be concluded that the influence of WOM on the purchase of intrusions of local, domestic and foreign tourists is because WOM is the easiest way for tourists to find information about gift from West Sumatra as gift from the tourists visiting West Sumatra. The results of this study are in line with the results of the research conducted by Rachman and Abadi (2017), Li et al (2017), Yasri\&Engriani (2018) and in accordance with the theory of Chowtanapanich, and SirionChaipoopirutana (2014) in their research entitled "Identifying Factor Influence Purchase of Intention of Non-Blackmores Users "revealed that WOM communication had a positive effect on purchase intention.

\section{Conclusions}

Based on the results of the research described in the previous chapter, conclusions can be drawn as follows:

1. Product Attributes have a positive and significant effect on the purchase intention of gift products typical of West Sumatra. This means that the more often looking for information about products, product quality and prices of gift products typical of West Sumatra food, the more it gives influence to the purchase intention of gift products typical of West Sumatra food.

2. Personality has a positive and significant effect on the purchase intention of gift products typical of West Sumatra. This means that the personalities of local, domestic and foreign tourists about their feelings, attitudes and actions towards gift products from West Sumatra are an encouragement to shop for food gift for their visit to West Sumatra.

3. WOM has a positive and significant effect on the purchase intention of gift products typical food of West Sumatra. This means that the more often seen, heard and recommended both directly from the closest person and in the form of EWOM that is encountered by tourists through social media about reviews, advertisements or reviews of influencers on gift products typical of West Sumatra, the prospective consumer purchase intention becomes higher.

\section{References}

Chowtanapanich, \& Chaipoopirutana. (2014). Identifying Factors Influencing Purchase Intentions of NonBlackmores Users. https://doi.org/10.15242/icehm.ed0814094

Dodds, W. B., Monroe, K. B., \& Grewal, D. (2006). Effects of Price, Brand, and Store Information on Buyers' Product Evaluations. Journal of Marketing Research. https://doi.org/10.2307/3172866 
Evanita, S., \& Trinanda, O. (2018). Marketing to $1 Z$ Generationsr: An Analysis of West Sumaterars Youth Decision Factors When Buying Modern Snacks a Minangkabau Traditional Snacks. https://doi.org/10.2991/piceeba-18.2018.42

Ghoni, A dan Bodroastuti, T. (2012). Pengaruh Factor Budaya Social, Pribadi Dan Psikologi Terhadap Perilaku Konsumen (Studi Kasus Pada Pemebelian Rumah Di Perumahan Griya Utama Banjardowo Semarang). Sekolah Tinggi Ilmu Ekonomi Widya Manggala. Jurnal Kajian Akuntansi Dan Bisnis 1 (1).

Hair, J.F., Hult, G.T.M., Ringle, C.M. and Sarstedt, M. (2014). A Primer on Partial Least Squares StructuralEquation Modeling (PLS-SEM).Sage, Thousand Oaks. https://doi.org/10.1108/EBR-10-20130128

Jin, B., \& Kang, J. H. (2011). Purchase intention of Chinese consumers toward a US apparel brand: A test of a composite behavior intention model. Journal of Consumer Marketing. https://doi.org/10.1108/07363761111127617

Jundong, H., Lanying, D., \& Jianfeng, L. (2008). Cause's attributes influencing consumer's purchasing intention: empirical evidence from China. Asia Pacific Journal of Marketing and Logistics.

Khare, A., Khare, A., \& Singh, S. (2010). Role of consumer personality in determining preference for online banking in India. Journal of Database Marketing and Customer Strategy Management. https://doi.org/10.1057/dbm.2010.18

Kolopita, D. A., \& Soegoto, A. S. (2015). Analisis Atribut Produk dan Harga Terhadapat Minat Beli Mobil Suzuki Ertiga di Kota Manado. Analisis Atribut Produk.

Kotler, P., \& Armstrong, G. (2018). Principles in Marketing Chapter 1. In Principles of Marketing.

Kotler, P., \& Keller, K. L. (2018). Marketing Management. Global Edition (Vol. 15E). https://doi.org/10.1080/08911760903022556

Lee, W. I., Cheng, S. Y., \& Shih, Y. T. (2017). Effects among product attributes, involvement, word-ofmouth, and purchase intention in online shopping. Asia Pacific Management Review. https://doi.org/10.1016/j.apmrv.2017.07.007

Li P, Xiaofan Yang, Lu-Xing Yang, Qingyu Xiong, Yingbo Wu,Dan Yuan Yan Tang. (2018). The Modeling And Analysis Of The Word-Of-Mouth Marketing. Physica A. https://doi.org/10.1016/j.phy

McGriff, J. A. (2012). A Conceptual Topic in Marketing Management: The Emerging Need for Protecting and Managing Brand Equity: The Case of Online Consumer Brand Boycotts. International Management Review.

Novita, P. dan Lubis, AR. (2018). Pengaruh Kepribadian Terhadap Loyalitas Dengan Persepsi Kualitas Merek Dan Niat Beli Sebagai Variabel Mediasi (Studi Pasa Retailer Showroom Mobil Toyota Di Banda Aceh). Jurnal Ilmiah mahasiswa Ekonomi Manajemen Vol.3, No 2 Mei:148-161. E-ISSN: 2598$635 X$.

Paul, J., \& Rana, J. (2012). Consumer behavior and purchase intention for organic food. Journal of Consumer Marketing. https://doi.org/10.1108/07363761211259223

Peter, J. P., \& Olson, J. C. (2009). Perilaku Konsumen dan Strategi Pemasaran. salemba empat. https://doi.org/10.1038/sj.gt.3301994

Rachman, R. Dan Abadi, Tw.(2017). Komunikasi Word Of Mouth Dan Keputusan Pembelian Batik Bangkalan. Jurnal ASPIKOM. Vol 3, No 2. Januari 207, Hal 285-295. ISSN: 2087-0442.

Rahayu, Deny Danar. (2014). Pengaruh Word Of Mouth Dan Brand Community Komunitas

Schiffman, L. G., \& Kanuk, L. L. (2000). Consumer behavior, 7th. In Consumer behavior, 7th.

Setyanto, Linggar Eka Z. A. dan S. (2017). Pengaruh Atribut Produk Terhadap Keputusan Pembelian (Survei Pembeli Apple iPhone pada Mahasiswa/Mahasiswi S1 Fakultas Ilmu Administrasi Program Studi Ilmu Administrasi Bisnis Angkatan 2013/2014 Universitas Brawijaya Malang). Jurnal Administrasi Bisnis (JAB).

Sidik, M. R., \& Saino. (2014). Pengaruh Persepsi Atribut Produk Terhadap Minat Beli Konsumen Pada 
Produk Sepeda Motor Yamaha R15 Di Surabaya Dengan Kepercayaan Merek Sebagai Variabel Intervening, 1-9.

Thu Ha, Nguyen \& Gizaw, A. (2014). Factors That Influence Consumer Purchasing Decisions Of Privat Label Food Products A Case Study Of ICA Basic. www.diva-portal.org>get $>$ fulltex01

Yasri. (2009). Faktor-Faktor Yang Mempengaruhi Reputasi Pariwisata Dengan Word of Mouth (WOM) Sebagai VariabelMediasi Studi Atas Wisatawan Yang Berkunjung ke Sumatera Barat. Jurnal Mangemen Bisnis \& Publik, 1(2), 69-139.

Yasri. (2015). Keunggulan Bersaing Produk Makanan Umkm Dibanding Industri Besar Di Sumbar MADIC Startegy : Thrive in Turbulent Environment ( Research And Practices )

Yasri Dan Engriani, Yunita. (2018). An Analysis On Brand Image And Switching Intention Of Flight Companies'Customers With Word Of Mouth (Wom) As The Intervening Variable. Atlantis Press Advances In Economics, Business And Management Research, Volume 57. Advances In Economics, Business And Management Research, Volume 57. CCBY-NC (http://creativecommons.org/licenses/by$\underline{\mathrm{nc} / 4.0 /)}$. 